\title{
PENGARUH KEPUASAN KERJA TERHADAP KINERJA KARYAWAN
}

\author{
Mutiara Islami Putri 17002020
}

Email : mutiaraislami2017@gmail.com

\begin{abstract}
Abstrak
Penelitian ini dilaksanakan untuk mengetahui dan menjelaskan pengaruh kepuasan kerja terhadap kinerja karyawan. Terdapat beberapa masalah dalam suatu organisasi, maka peran pemimpin sangat diperlukan agar karyawan mampu meningkatkan performa dan hasil kerja mereka. Pemimpin mempunyai tanggung jawab untuk meningatkan kinerja karyawan dalam perusahaan. Oleh karena itu, sangat diperlukan sekali memberikan kepuasan kerja kepada karyawan agar dapat menumbuhkan kesadaran diri karyawan untuk memaksimalkan potensi dirinya untuk melakukan pekerjaan.
\end{abstract}

\section{Kata kunci : kepuasan kerja, kinerja karyawan}

\section{PENDAHULUAN}

Setiap karyawan akan membandingkan sesuatu hal yang didapat dari perusahaan dengan sesuatu yang diberikannya terhadap perusahaan. Perbandingan tersebut akan menimbulkan persepsi karyawan terhadap pekerjaannya dalam perusahaan.

Kepuasan kerja dapat menentukan sikap karyawan terhadap pekerjaannya, Kondisi pekerjaan yang memberikan kenyamanan dan mendukung pekerjaannya, akan membuat karyawan merasa tenang dalam bekerja. Perusahaan yang memberikan kesempatan karyawan untuk maju dalam bekerja baik itu berupa pengetahuan maupun jabatan yang lebih tinggi, akan berdampak pada kepuasan karyawan mengenai kebutuhan akan aktualisasi diri dan dihargai dalam organisasi.

Saat melakukan pekerjaan, karyawan akan menilai pekerjaan yang dilakukannya. Tugas yang dikerjakan tidak menimbulkan kesulitan ataupun kebosanan. Tugas yang dikerjakan sesuai dengan minat, kemampuan, dan pendidikan. Tugas yang dikerjakan menimbulkan rasa senang, kebanggaan, dan memberikan tanggung-jawab.

Dalam menyelesaikan pekerjaan karyawan membutuhkan rekan kerja yang membantu menyelesaikan pekerjaan. Karyawan akan merasa bergairah dalam bekerja dengan adanya hubungan yang baik dengan rekan kerja dan pimpinanya. Rekan kerja yang memberi dorongan moril, memberikan saran dan nasihat membantu karyawan dalam berprilaku dalam 
perusahaan. Pengawasan atau supervisi yang memberikan dorongan, membimbing, dan mengarahkan karyawannya agar bekerja sesuai dengan ketentuan perusahaan.

Kinerja atau performa kerja karyawan yang baik dapat menjadi keistimewaan tersendiri bagi sebuah perusahaan. Istilah kinerja karyawan didefinisikan sebagai prestasi atau hasil kerja (output) baik kualitas maupun kuantitas yang dicapai oleh seorang pegawai dalam melaksanakan tugas kerjanya sesuai dengan tanggungjawab yang diberikan. Kinerja atau performa kerja karyawan yang baik dapat menjadi keistimewaan tersendiri bagi sebuah perusahaan. Istilah kinerja karyawan didefinisikan sebagai prestasi atau hasil kerja (output) baik kualitas maupun kuantitas yang dicapai oleh seorang pegawai dalam melaksanakan tugas kerjanya sesuai dengan tanggungjawab yang diberikan (Mangkunegara, 2002:67). Pada umumnya, kinerja dievaluasi berdasarkan kualitas kerja, kuantitas kerja dan ketepatan waktu. Dimensi yang dimiliki kinerja karyawan dapat memunculkan daya saing suatu perusahaan dengan kompetitornya. Perusahaan dengan kinerja karyawan yang baik dapat dengan mudah mencapai tujuan yang diinginkan, yang juga menjadikannya lebih unggul dari para pesaing

\section{Rumusan masalah}

Bagaimana tindak lanjut yang seharusnya dilakukan oleh pemimpin dalam menyikapi seorang karyawan yang belum puas terhadap kinerjanya dan bagaimana cara pemimpin meningkatkan kepuasan kerja karyawan karena seperti yang kita ketahui kepuasan kerja sangat berpengaruh terhadap kinerja pegawai

\section{Tujuan pembahasan}

Jurnal ini dibahas dengan tujuan untuk mengetahui bagaimana kinerja pegawai dalam suatu perusahaan sehingga menghasilkan kepuasan kerja

\section{PEMBAHASAN}

\section{Kajian Pustaka}

Kepuasan kerja adalah suatu ungkapan perasaan atau sikap seseorang terhadap pekerjaannya, terhadap kesempatan promosi, hubungan dengan rekan kerja, pengawasan dan perasaan puas terhadap pekerjaan itu sendiri menurut Titisari (Rindiantika, 2018)

Kepuasan menurut para ahli salah satunya adalah S.P. hasibuan, menurutnya kepuasan kerja adalah kondisi emosional pada seseorang pegawai yang sennag dan mencitai 
pekerjaannya. Sikapiniterlihatdari moral kerja, kedisiplinan dan prestasi kerja.Hal ini dapat dinikmati dalam pekerjaan, di luar pekerjaan, dan kombinasi dari keduanya.

\section{Teori-Teori Kepuasan Kerja}

Teori kepuasan kerja yang dikemukakan oleh Mangkunegara (Kurnia, 2017)

1) Teori keseimbangan (equity theory), teori ini dikembangkan oleh Adams. Wexley dan Yukl dalam mengemukakan komponen utama dari teori ini adalah : Input adalah suatu nilai yang diberikan karyawan saat melaksanakan pekerjaannya, Outcome adalah semua nilai yang diperoleh karyawan dari pekerjaannya, Comparison person adalah seorang pegawai yang berada dalam organisasi yang sama ataupun diluar organisasi, atau dirinya sendiri dalam pekerjaan sebelumnya, Equity - inequity adalah suatu yang dirasakan karyawan adil atau tidak adil.

2) Teori perbedaan (discrepancy theory), teori ini pertama kali dikemukan oleh Porter. Ia berpendapat bahwa mengukur kepuasan kerja dapat dilakukan dengan cara menghitung selisih antara apa yang seharusnya dengan kenyataan yang dirasakan pegawai. Locke (1996) mengemukakan bahwa kepuasan kerja pegawai bergantung pada perbedaan antara apa yang didapat dan apa yang diharapkan oleh pegawai.

3) Teori pemenuhan kebutuhan (need fulfillment theory), menurut teori ini kepuasan kerja pegawai bergantung pada terpenuhinya atau tidak nya kebutuhan pegawai.

4) Teori pandangan kelompok (social reference group theory), pada teori ini, kepuasan kerja karyawan bukanlah bergantung pada pemenuhan kebutuhan saja, tetapi juga bergantung pada pandangan dan pendapat kelompok yang dianggap sebagai kelompok acuan.

5) Teori dua faktor dari Herzberg, berdasarkan teori ini kepuasan kerja dan ketidakpuasan kerja itu terpisah dan berbeda. Teori ini merumuskan dua faktor yaitu satisfies atau motivators dan dissatisfies atau hygiene factors.

6) Teori pengharapan (expectancy theory) Vroom menjelaskan bahwa motivasi merupakan suatu produk dari bagaimana seorang menginginkan sesuatu, dan penaksiran seseorang memungkinkan aksi tertentu yang menuntunnya".

Kepuasan kerja penting untuk dimunculkan dalam pelaksanaannya beririsan dengan pemenuhan kebutuhan mneurut Mangkunegara (Rindiantika, 2018). Tidak dapat dipungkiri bahwa tujuan seseorang bekerja adalah untuk memenuhi kebutuhan. Karyawan akan merasa puas apabila mendapatkan apa yang dibutuhkan dan diharapkan, semakin besar kemungkinan 
item kebutuhan mereka terpenuhi, maka kepuasannya akan semakin meningkat atau sebaliknya. Oleh sebab itu, dorongan kepuasan kerja berhubungan dengan performa kerja mereka.

Seperti yang dikatakan oleh Ermita (Ermita, 2012) Pegawai merupakan komponen yang memegang peranan utama dalam organisasi, karena pegawai bertanggung jawab untuk kegiatan atau pelaksanaan program yang telah disusun. Disamping itu pegawai juga juga merupakan faktor utama (vital) dalam pelaksanaan tugas program-program yang telah ditetapkan organisasi. Kinerja adalah prestasi kerja atau hasil kerja (output) baik kualitas maupun kuantitas yang dicapai oleh seorang pegawai dalam melaksanakan tugas kerjanya sesuai dengan tanggungjawab yang diberikan kepadanya.

Seperti yang dikemukakan oleh Rindiantika (Rindiantika, 2018) Karyawan yang merasa keinginan dan harapannya terpenuhi oleh perusahaan, dengan kata lain puas akan pekerjaannya, maka secara mandiri mereka akan dengan suka rela melakukan hal-hal yang menguntungkan bagi perusahaan

\section{Tolak Ukur Kepuasan Kerja}

Dalam mengukur tingkat kepuasan kerja seseorang perlu diketahui faktor-faktor apa saja yang menjadi tolak ukurnya. Robbins (Rindiantika, 2018) menjelaskan lima faktor yang dapat menjadi tolak ukur kepuasan kerja, antara lain:

1. Kepuasan dengan gaji

2. Kepuasan dengan promosi

3. Kepuasan dengan rekan kerja

4. Kepuasan dengan atasan

5. Kepuasan dengan pekerjaan itu sendiri

\section{Kajian analitis}

Kepuasan kerja berpengaruh terhadap kinerja karyawan. Semakin puas karyawan dengan gaji, promosi, rekan kerja, atasan, dan pekerjaan itu sendiri, maka kinerja karyawan yang ditunjukkan melalui kualitas, kuantitas, dan ketepatan waktu akan semakin tinggi. Kepuasan kerja memiliki pengaruh positif dan signifikan terhadap kinerja pegawai. Semakin besar kesempatan pemenuhan indikator-indikator kepuasan kerja, maka perilaku atau kinerja pegawai yang ditunjukkan akan semakin kuat. 
Terkait masalah yang dibahas di atas, apabila ada seorang pegawai atau karyawan yang tidak memiliki kepuasan terhadap pekerjaan yang dia lakukan maka seorang pemimpinharus menindaklanjuti hal tersebut. seorang pemimpin harus bisa menjalankan perannya untuk membangkitkan semangat pada karyawannya. Dengan memberikan Motivasi kerja tentunya akan berpengaruh pada peningkatan kinerja karyawan, jika kinerja karyawan meningkat maka akan menghasilkan sesuatu yang bagus pula pada sebuah organisasi, jika sebuah organisasi mendapatkan hasil yang bagus maka pemimpin akan bangga kepada pegawainya karena telah bisa mencapai hasil yang diinginkan, karyawan pun akan menjadi puas dan bangga terhadap pekerjaannya karena pemimpin memberikan kompensasi, gaji atau reard dan semacamnya untuk karyawan sebagai tanda terimakasih dan agar karyawan selalu meningkatkan kinerja nya dalam melakukan pekerjaan.

Terkait permasalahan kedua, bagaimana cara pemimpin meningkatkan kinerja pegawai yaitu pemimpin mampu melakukan evaluasi kinerja dan pemberian motivasi atau komponen kompensasi lainnya yang membuat karyawan mampu meningkatkan performa dan hasil kerja mereka. Tekait dengan kepuasan kerja, perusahaan telah berhasil memenuhi sebagian besar item dan banyak diantaranya mendapatkan perolehan yang baik atau cukup. Namun, dimensi atasan yang adil mendapat perolehan yang rendah. Perusahaan diharapkan melakukan peninjauan terkait dengan hal ini, sebab apa yang diungkapkan karyawan berbeda dengan tim perusahaan.

\section{PENUTUP}

\section{Kesimpulan}

Kepuasan kerja memiliki pengaruh positif dan signifikan terhadap kinerja karyawan. Semakin besar kesempatan pemenuhan indikator-indikator kepuasan kerja, maka perilaku dan kinerja yang ditunjukkan pegawai akan semakin kuat. Kepuasan kerja berpengaruh terhadap kinerja karyawan. Semakin puas karyawan dengan gaji, promosi, rekan kerja, atasan, dan pekerjaan itu sendiri, maka kinerja karyawan yang ditunjukkan melalui kualitas, kuantitas, dan ketepatan waktu akan semakin tinggi.

\section{Saran}

Terkait kinerja karyawan yang tergolong cukup, peneliti menyarankan bahwa perusahaan mampu melakukan evaluasi kinerja dan pemberian motivasi atau komponen 
kompensasi lainnya yang membuat karyawan mampu meningkatkan performa dan hasil kerja mereka. Tidak dapat dipungkiri bahwa menyinggung finansial dan kebutuhan efektif untuk menumbuhkan kesadaran diri karyawan untuk memaksimalkan potensi dirinya untuk melakukan pekerjaan

\section{Referensi}

Ermita. (2012). Hubungan Antar Manusia dan Semangat Kerja. Pedagogi, Jurnal Ilmu Pendidikan, XII(2), 1-81. Retrieved from http://ejournal.unp.ac.id/index.php/pedagogi/article/view/2200

Kurnia, D. (2017). PENGARUH KEPUASAN KERJA TERHADAP DISIPLIN KERJA DAN KOMITMEN ORGANISASIONAL. Jurnal Administrasi Bisnis, 44(1), 1-39.

Rindiantika, O. (2018). PENGARUH KEPUASAN KERJA TERHADAP KINERJA KARYAWAN DENGAN ORGANIZATIONAL CITIZENSHIP BEHAVIOR SEBAGAI VARIABEL INTERVENING. Jurnal Administrasi Bisnis, 64(1), 1-35. 